\title{
Bioactive compounds in edible flowers of garden pansy in response to irrigation and mycorrhizal inoculation ${ }^{1}$
}

\author{
Joelma Gonçalves ${ }^{2 *}$ (D) João Carlos Ferreira Borges Júnior ${ }^{2}$, Lanamar de Almeida Carlos ${ }^{2}$, \\ Ana Paula Coelho Madeira Silva ${ }^{2}$,Francisco Adriano de Souza ${ }^{3}$
}

10.1590/0034-737X201966060001

\begin{abstract}
Edible flowers have been increasingly used in the Brazilian gastronomy because they are considered functional foods with high antioxidant potential. Studies on the management of cultivation of edible flowers to increase the production of bioactive compounds have been developed aiming at the improvement of production systems. The objective of this work was to evaluate the production of bioactive compounds in garden pansy (Viola wittrockiana Gams ex Nauenb. \& Buttler) plants submitted to different levels of irrigation and mycorrhizal inoculation. The greenhouse experiment was conducted in randomized blocks in a $2 \times 5$ factorial design with the presence and absence of mycorrhizal inoculation in combination with 5 levels of water evaporation $(120 \%, 100 \%, 80 \%, 60 \%$ and $40 \%)$ replaced by irrigation, totaling 10 treatments with 6 replicates. The contents of bioactive compounds (total phenolic compounds, flavonoids and total anthocyanins) present in the flowers, collected over the reproductive period, were evaluated. There was a significant interaction between the factors mycorrhizal inoculation and irrigation levels by $F$ test $(p<0.05)$ for total flavonoids and anthocyanins. The best results in the production of bioactive compounds were obtained for irrigation at the $100 \%$ replenishment level of water evaporation without the presence of mycorrhizal inoculation.
\end{abstract}

Keywords: functional foods; unconventional food plants (UFP); mycorrhizal fungi; water deficit

\section{INTRODUCTION}

The terms "productive landscaping or edible garden" are increasingly used in floriculture and are defined as the creation of macro and micro-landscapes, with intensive use of plants, in order to produce food (grains, fruits, vegetables, herbs and others), respecting natural processes and cycles, and integrated with the ecosystem of each site, maintaining or increasing biodiversity (Reis et al., 2004; Antônio, 2013). The use of unconventional food plants (UFP) in these environments, especially plants with edible flowers, brings visual well-being, colors the environment, maximizes the use of local biodiversity, diversifies the menu and nutrients ingested, and generates new sources of income (Kinupp \& Lorenzi, 2014).
Garden pansy (Viola wittrockiana Gams ex Nauenb. $\&$ Buttler - Violaceae Family) is considered one of the preferred species to compose landscapes and gardens due to its varied color combination in flowers. Its edible flowers with velvety texture and slightly sweet taste can be used in the preparation of desserts, salads, soups, beverages or for decoration of dishes. They have good antioxidant activity and contain bioactive compounds and can be used as functional food (Vukics et al., 2008; Kinupp \& Lorenzi, 2014; Skowyra et al., 2014). It also has the ability to prevent neurodegenerative diseases (Mousavi etal., 2016).

The bioactive compounds can combat oxidative processes triggered by free radicals normally produced

\footnotetext{
Submitted on March 19 th, 2019 and accepted on October $06^{\text {th }}, 2019$.

'This work is part of the master's thesis of the first author.

${ }^{2}$ Universidade Federal de São João del-Rei, Departamento de Ciências Agrárias, Sete Lagoas, Minas Gerais, Brasil. joelma_gon@yahoo.com.br; jcborges@ufsj.edu.br; lanamar@ufsj.edu.br; anapaula@ufsj.edu.br

${ }_{3}^{3}$ Embrapa Milho e Sorgo, Núcleo de Biologia Avançada, Sete Lagoas, Minas Gerais, Brasil. francisco.adriano@embrapa.br

*Corresponding author: joelma_gon@yahoo.com.br
} 
during metabolism. Free radicals react with other organic substances and cause damage to cells, genetic material and tissues. The damages are cumulative and can lead to the development of cardiovascular diseases, cancer, diabetes, obesity, osteoporosis and other chronic non-communicable diseases (Chitarra \& Chitarra, 2005). Studies confirm the presence of bioactive compounds in flowers of passionflower, yellow and pink carnation, Tropaeolum majus L., dahlia, broccoli, and garden pansy (Vieira, 2013; Costa et al., 2014; Lara-Cortés et al., 2014).

Variations among species, flowering period, soil, climate and crop management may alter the profile and contents of bioactive compounds in plants (Fernandes et al., 2016). Aleman \& Marques (2016) verified that total flavonoid production and content showed a progressive increase as the levels of applied water depths associated with the highest dose of organic fertilization (chicken litter) were increased. In the studies carried out by Bortolo et $a l .$, (2009), when evaluating the flavonoid content in calendula cultivated with different irrigation depths, no changes were observed in the flavonoid content as a function of the applied water.

The increase in the production of bioactive compounds can occur in plants inoculated with arbuscular mycorrhizal fungi (AMF) (Kiriachek et al., 2009). The symbiosis between host plant and fungus influences several aspects of plant physiology, such as nutrition, growth, development and protection of plants against abiotic or biotic stresses (Azcón-Aguilar \& Barea, 1997).

Thus, the hypothesis that the water supply according to the full evapotranspirometric demand of the crop, together with the use of AMF, influences the production of bioactive compounds in flowers of garden pansy plants was formulated.

The objective of this study was to evaluate the production of bioactive compounds in edible flowers of the Majestic Giants II Rosalyn cultivar of garden pansy (Viola wittrockiana) plants under the presence or absence of mycorrhiza and different irrigation levels $(120 \%, 100 \%$, $80 \%, 60 \%$ and $40 \%$ of water evaporation replacement) in a greenhouse.

\section{MATERIAL AND METHODS}

The experiment was carried out in a greenhouse at the Federal University of São João del-Rei, Campus Sete Lagoas, located about $70 \mathrm{~km}$ from Belo Horizonte, whose geographical coordinates are latitude $19^{\circ} 28^{\prime} 4$ " South and longitude $44^{\circ} 14^{\prime} 52^{\prime \prime}$ West. The temperature and relative air humidity inside the greenhouse were monitored daily with the use of a digital thermo-hygrometer of the Incoterm ${ }^{\circledR}$ brand model 7666.02.0.00.
Seeds of the Majestic Giants II Rosalyn cultivar of garden pansy (Viola wittrockiana) were used in this study. The S2 hybrid seeds, lot 99.173 , were commercially produced in Japan and purchased from Sakata ${ }^{\circledR}$. The seeds were of the F1 generation, demonstrated 93\% germination and had a physical purity of $99.9 \%$. Three seeds were sown per cell after breaking dormancy in distilled water for 30 minutes (Fernandes et al., 2015).

Sowing was performed in cell trays composed of small round tubes with 6 grooves and 1 drainage hole at the bottom. The capacity of each individual cell was $55 \mathrm{~cm}^{3}$. The substrate used in the sowing trays was composed of commercial vegetable soil (brand Terra de Minas, Contagem, Minas Gerais) without mineral fertilization, plus vermicompost (brand Adubos Bom Jardim, Contagem, Minas Gerais) in the volumetric ratio of $3: 1$, which was previously homogenized, moistened and solarized in a solar collector for 24 hours at approximately $60^{\circ} \mathrm{C}$ (Ghini, 2004).

Two plants were transplanted per pot at 52 days after sowing (DAS), which constituted the experimental units. Common black pots composed of polyethylene $\mathrm{n}^{\circ} 3$ with a capacity of $3.1 \mathrm{~L}$ and dimensions of $17 \mathrm{~cm}$ in height, $23 \mathrm{~cm}$ diameter at the top and $14.5 \mathrm{~cm}$ in diameter at the base (mark Tetraplast) were used. The pots were lined with drainage blankets and placed on plates. Prior to transplanting, the substrate used to fill the pots was moistened and solarized in the solar collector for 24 hours at approximately $60{ }^{\circ} \mathrm{C}(\mathrm{Ghini}, 2004)$. The substrate was composed of typical Cerrado soil homogenized with sand and organic matter in the volumetric ratio of $2: 1 \cdot 5: 0.5$. An average mass of $2,255.45 \mathrm{~g}$ of substrate was used, with a standard deviation of $0.019 \mathrm{~g}$. The substrate was submitted to physicochemical analysis in the LABORSOLO laboratory (Paraná, Brazil). The physical-chemical analysis of the substrate used for garden pansy plants production showed low phosphorus content (Table 1).

The experiment started with sowing in May 2017 and ended in September 2017. The experimental design was a randomized block with a $2 \times 5$ factorial scheme with two levels of mycorrhizal inoculation (absence and presence) and five irrigation levels $(120 \%, 100 \%, 80 \%, 60 \%$ and $40 \%$ of evaporation replacement) with 6 replicates, totaling 10 treatments and 60 experimental units.

The soil inoculum was obtained from the Nucleus of Applied Biology (NBA) of Embrapa Milho e Sorgo. It contained the fungus Claroideoglomus etunicatum CNPMS09 (W.N. Becker \& Gerd. and C. Walker \& A. Schüßler) with approximately 120 spores per $\mathrm{cm}^{3}$. The research is registered in the SISGEN under the number A894B2E for the access to Brazilian genetic patrimony fungus - C. etunicatum, in compliance with Law $\mathrm{n}^{\circ} 13,123$ / 2015 and its regulations. 
According to the treatment groups, the inoculant based on the inoculum soil was added to the substrate of the sowing trays in the proportion of $20 \%$ of the substrate volume on the same day of sowing. That soil-inoculum substrate ratio provides approximately 1300 spores per tray cell. To equilibrate the microbiota of the substrate of the seed trays, $1 \mathrm{~mL}$ of the inoculum suspension filtrate was added to each tube. This filtrate was made from the homogenization of $100 \mathrm{~g}$ of inoculated soil added to $1 \mathrm{~L}$ of autoclaved distilled water.

The quantification of spore density was performed at the end of the experiment at the Microbial Molecular Ecology Laboratory of the Applied Biology Center, Embrapa Milho e Sorgo. To estimate mycorrhizal colonization, the finer roots were separated from the root system. After that, the roots were washed in running water and conditioned in 50\% alcohol until clarified. Next, the roots were clarified with $10 \%$ potassium hydroxide solution $(\mathrm{KOH})$ in a water bath at $90{ }^{\circ} \mathrm{C}$ for 1 hour. They were then washed in tap water and acidified with $2 \%$ hydrochloric acid $(\mathrm{HCl})$ at room temperature for 24 hours. Subsequently, the roots were removed from the $\mathrm{HCl}$ solution and placed in Trypan blue dye solution at $0.05 \%$ in a water bath at $60{ }^{\circ} \mathrm{C}$ for 45 minutes (Phillips \& Hayman, 1970). The mycorrhizal colonization rate was estimated using the magnified gridline intersection method (Giovanetti \& Mosse, 1980). The structures that characterize the mycorrhizal association, such as hyphae, arborescence and vesicles in fragments of the pansy roots using a stereomicroscope model Zeiss SV11 were then quantified.

Samples were irrigated to fill $100 \%$ of the water retention capacity of the substrate during seedling production and the establishment period. The application of different levels of irrigation was initiated according to the measurement of the evaporation of the water from the pots with uncultivated soils (monitoring pots) using weight at 9 days after transplanting (DAT), that is, 60 DAS. Evaporation was measured daily and volumes of water were applied to the monitoring pots to attain the predetermined pot capacity. Daily manual irrigation was performed, applying 120\%, 100\%, 80\%, $60 \%$ and $40 \%$ of the evaporation volume.

The evaluation of the bioactive compounds was performed only on the flowers of pansy. Flowers fully opened were collected without petiole weekly, early in the morning. Then, the flowers were stored in plastic bags and taken to the UFSJ (Campus Sete Lagoas) Food Storage Laboratory, where they were frozen at $-20{ }^{\circ} \mathrm{C}$ for further analysis in duplicate (Figure 1).

The content of total phenolic compounds (CFT) was quantified using the methodology of the modified FolinCiocalteau reagent (Singleton et al., 1999). For this, 0.5 $\mathrm{g}$ of the macerated flower samples were weighed, and $70 \%$ ethanol was added in enough quantity to make up the volume to $7.5 \mathrm{~mL}$. It was vortexed and placed on the ultrasonic sonicator for 5 minutes, subjected to heating in a water bath for 30 minutes at $50{ }^{\circ} \mathrm{C}$ and then centrifuged for 10 minutes at $3600 \mathrm{rpm}$. An aliquot of $0.5 \mathrm{~mL}$ of the supernatant was transferred to an amber tube and $2.5 \mathrm{~mL}$ of Folin-Ciocalteau solution (F.C.) was added. After 5 minutes, $2 \mathrm{~mL}$ of sodium carbonate $\left(\mathrm{Na}_{2} \mathrm{CO}_{3}\right)$ solution was added. The samples were left standing for 2 hours in the dark. The reading was performed in a FEMTO spectrophotometer at $760 \mathrm{~nm}$ absorbance. The results were calculated based on a standard curve of gallic acid $\left(y=0.0025 x+0.5113 ; \mathrm{R}^{2}=\right.$ $0.96)$ and expressed in mg equivalents of gallic acid (EGA) $100 \mathrm{~g}^{-1}$ of wet flower (Neves et al., 2009) and in mg per plant EGA.

Table 1: Physical-chemical characteristics of macro and micronutrients of the substrate used in the production of garden pansy plants (Viola wittrockiana)

\begin{tabular}{lcc}
\hline Analyze & In Nature & Dry Base $\left(\mathbf{6 5}^{\circ} \mathbf{C}\right)$ \\
\hline $\mathrm{pH}$ in $\mathrm{CaCl}_{2} 0.01 \mathrm{~m}$ & 7.17 & \\
Electric conductivity $(\mu \mathrm{S} / \mathrm{cm})$ & $1.865 \times 10^{3}$ & 13.26 \\
Humidity lost at $65^{\circ} \mathrm{C}(\%)$ & 24.08 & 179.14 \\
WHC - Water holding capacity $(\%)$ & 10.07 & 2.62 \\
$\mathrm{CEC}$ - Cation exchange capacity $\left(\mathrm{mmol}_{\mathrm{c}} \mathrm{kg}^{-1}\right)$ & 136.00 & 320.34 \\
\hline Total phosphorus - P $\left(\mathrm{mg} \mathrm{kg}^{-1}\right)$ & 1.99 & 231.56 \\
Total potassium - $\mathrm{K}^{+}\left(\mathrm{mg} \mathrm{kg}^{-1}\right)$ & 243.20 & 85.06 \\
Total calcium - $\mathrm{Ca}^{2+}\left(\mathrm{mg} \mathrm{kg}^{-1}\right)$ & 175.80 & 63.65 \\
Total magnesium - $\mathrm{Mg}^{2+}\left(\mathrm{mg} \mathrm{kg}^{-1}\right)$ & 64.58 & 0.03 \\
Total sulfur - $\mathrm{S}\left(\mathrm{mg} \mathrm{kg}^{-1}\right)$ & 48.32 & 1.36 \\
\hline Total copper - $\mathrm{Cu}^{2+}\left(\mathrm{mg} \mathrm{kg}^{-1}\right)$ & 0.02 & 0.00 \\
Total iron - $\mathrm{Fe}^{2+}\left(\mathrm{mg} \mathrm{kg}^{-1}\right)$ & 1.03 & 0.01 \\
Total manganese - $\mathrm{Mn}^{2+}\left(\mathrm{mg} \mathrm{kg}^{-1}\right)$ & 0.00 & 0.01 \\
Total zinc $-\mathrm{Zn}^{2+}\left(\mathrm{mg} \mathrm{kg}^{-1}\right)$ & & \\
\hline
\end{tabular}


The contents of total flavonoids (FLT) and anthocyanins (ANTT) were determined by Lees \& Francis (1971) methodology modified. An extraction solution of $\mathrm{HCl} 1.5 \mathrm{~N}+95 \%$ ethanol was added to $0.5 \mathrm{~g}$ of flower samples, which were macerated. The macerate was transferred to $25 \mathrm{~mL}$ volumetric flask, wrapped in foil, and the volume was completed with extractive solution. The samples stayed in the dark for 24 hours at $5^{\circ} \mathrm{C}$. After this period, filter paper filtering was performed and the FEMTO spectrophotometer readings were taken at 374 and 535 nm wavelengths for total flavonoid and anthocyanins, respectively. The results were expressed as $\mathrm{mg}$ of cyanidin3-glycoside (cyn-3-glu) $100 \mathrm{~g}^{-1}$ of wet flower and mg of per plant cyn-3-glu.

The assumptions of normality and homogeneity of the residual variances were verified by the Lilliefors and Levene tests, respectively. Box-Cox transformation (Box $\&$ Cox, 1964) was applied when the variables studied did not meet the assumptions of the statistical model, after which they were again analyzed according to the assumptions of the statistical model. The analysis of variance was then performed according to the randomized block model in the $2 \times 5$ factorial scheme due to the staggering of the experiment. Each analysis was performed with 6 replicates at the $5 \%$ level of significance.

For the variables for which there was a significant difference between the $\mathrm{F}$ test at the $5 \%$ level of significance in relation to the qualitative factor (absence and presence of mycorrhizal inoculation), the F test itself was used. In relation to the quantitative factor (irrigation levels), the regression analysis was applied at the 5\% level of significance. When a significant interaction between the factors studied was observed, the unfolding was performed. The ExpDes.pt package was used in the statistical program R, version 3.4.3 (R Core Team, 2017).

\section{RESULTS}

The means of maximum, minimum and mean daily temperatures during the execution period were $33.2{ }^{\circ} \mathrm{C}$, $13.8^{\circ} \mathrm{C}$ and $23.5^{\circ} \mathrm{C}$, respectively. The means of maximum, minimum and mean daily air relative humidity were $81.1 \%$, $29 \%$ and $55 \%$, respectively.

The mycorrhizal inoculation rate in garden pansy plants, which had received soil inoculum, presented a mean of $32 \%$ of root fragments colonized with the fungus Claroideoglomus etunicatum and $0 \%$ of colonization for the plants that did not receive inoculant.

The mean daily volume of water applied in the experimental units according to irrigation levels equivalent to $120 \%, 100 \%, 80 \%, 60 \%$ and $40 \%$ of evaporation (EV) during the experiment was $102,85,68,51$ and $34 \mathrm{~mL}$, respectively.

For the total phenolic compounds contents, extracted from the garden pansy flowers, when evaluated in $\mathrm{g}$ EAG $100 \mathrm{~g}^{-1}$ of fresh flower sample, there was no significant effect of the interaction and the main factors inoculation and irrigation. The mean total phenolic compounds content found in this study was $2.75 \mathrm{~g}$ EAG $100 \mathrm{~g}^{-1}$ fresh sample.

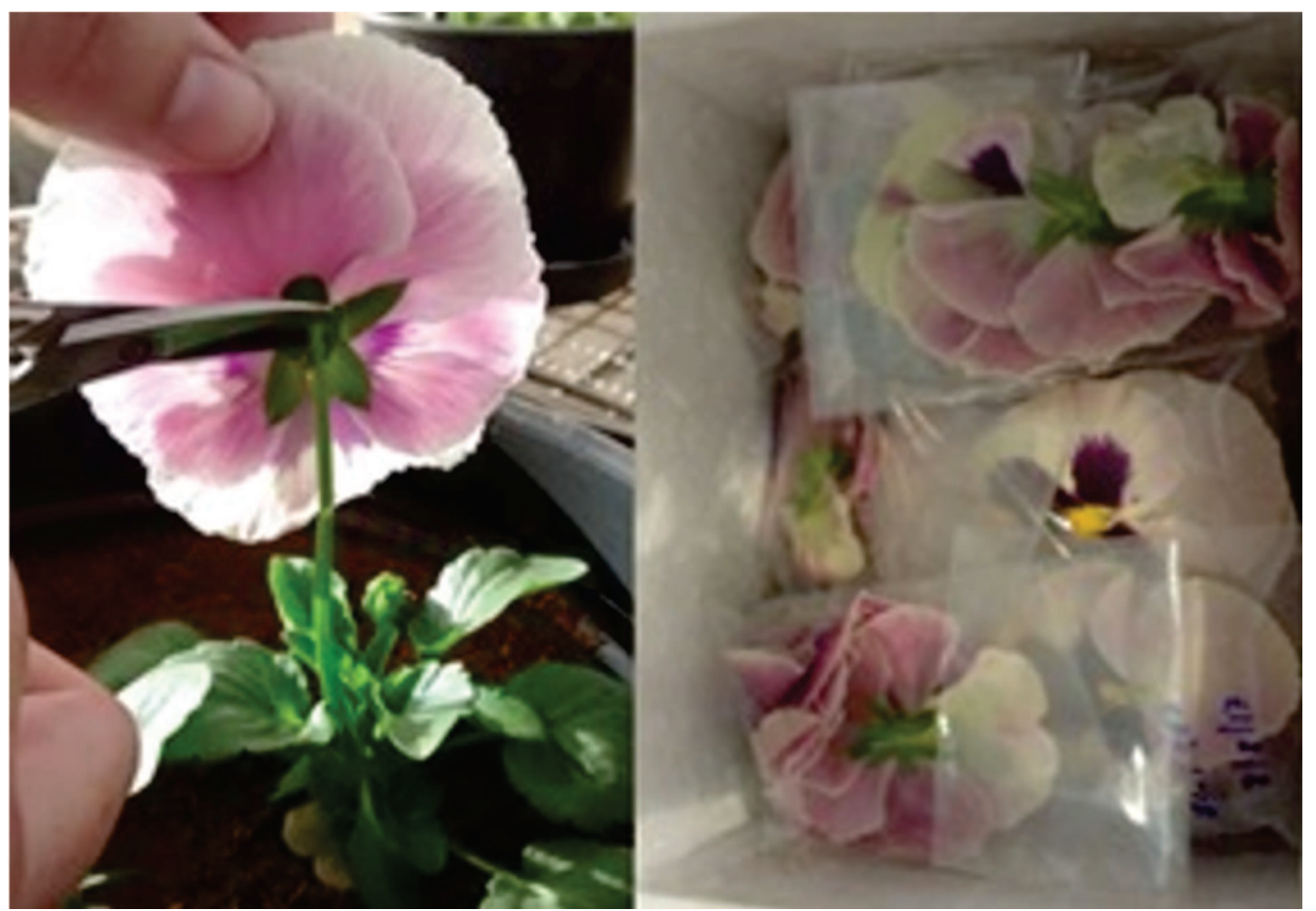

Figure 1: Collection (left) and storage (right) of garden pansy flower (Viola wittrockiana) for later analysis of bioactive compounds. Source: Personal archive.

Rev. Ceres, Viçosa, v. 66, n.6, p. 407-415, nov/dec, 2019 
The total flavonoids content, extracted from garden pansy flowers when evaluated in mg cyn-3-glu $100 \mathrm{~g}^{-1}$ of fresh flower sample, did not present a significant effect of the interaction between mycorrhizal inoculation and irrigation levels factors, thus, factors were assessed separately. The total flavonoid content did not present a significant difference in relation to the mycorrhizal inoculation factor and had a mean value of $503.31 \mathrm{mg}$ cyn3-glu $100 \mathrm{~g} \mathrm{~g}^{-1}$ of fresh sample. Regarding the irrigation factor, there was a significant difference between the levels studied for the total flavonoid content, but the mathematical model did not fit the data.

The total anthocyanins content, when evaluated in mg cyn-3-glu $100 \mathrm{~g}^{-1}$ of fresh flower sample, showed a significant effect of the interaction between mycorrhizal inoculation and irrigation levels factors. The highest total anthocyanin content (96.14 mg cyn-3-glu $100 \mathrm{~g}^{-1}$ fresh sample) was found in the unfolding of the interaction at the non-mycorrhizal level plus the $120 \%$ EV level (Table 2) and the lowest content $\left(50.90 \mathrm{mg}\right.$ cyn-3-glu $100 \mathrm{~g}^{-1}$ fresh sample) for a $76.87 \% \mathrm{EV}$ replacement without mycorrhiza (Figure 2). For the total anthocyanins content, there was no significant difference for irrigation levels in treatments with mycorrhizal presence.

The variable amount of total phenolic compounds extracted from the garden pansy flowers, when evaluated in $\mathrm{g}$ per plant EAG, transformed to meet the statistical assumptions of the model $(\lambda=0.16)$, did not present significant effect of the interaction between the mycorrhizal inoculation and irrigation levels factors, and also did not present a significant difference between mycorrhizal inoculation levels. However, there was a significant difference between irrigation levels fator with a quadratic trend and maximum amount of phenolic compounds in $107.84 \%$ of water evaporation (Figure 3 ).

The amount of total flavonoids extracted from garden pansy flowers when evaluated in mg per plant cyn-3-glu, transformed to meet the statistical assumptions of the model $(\lambda=0.10)$, showed a significant interaction effect between inoculation mycorrhizal and irrigation levels factors. The highest amount of total flavonoids occurred in the presence of mycorrhiza (M) plus the level of 100\% EV (61.89 mg per plant cyn-3-glu) and the smallest amount occurred in the presence of mycorrhizae (M) plus the level of $40 \% \mathrm{EV}$ (4.38 mg per plant cyn-3-glu) (Table 3). The effect of the interaction was significant and within the level of absence of mycorrhizal inoculation there was a linear tendency of the irrigation factor, with an increase of $0.0025 \mathrm{mg}$ per plant cyn-3-glu in the amount of total flavonoids with every $1 \%$ of evaporation replacement of water (Figure 4-a). Within the irrigation levels and the presence of mycorrhizal inoculation, the amount of total flavonoids showed a quadratic tendency with a maximum amount of $105.64 \%$ of water evaporation (Figure 4-b).

For the amount of total anthocyanins extracted from garden pansy flowers, when evaluated in mg per plant cyn-3-glu, transformed to meet the statistical assumptions

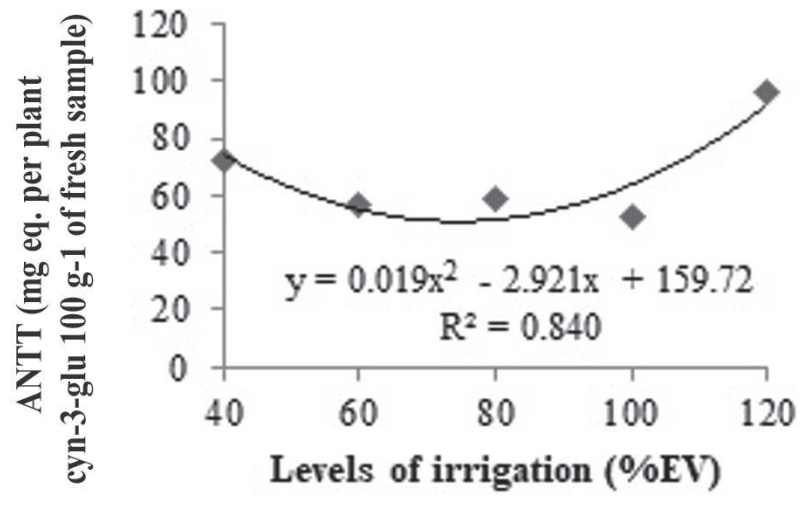

Figure 2: Total anthocyanins (ANTT) without presence of mycorrhizal inoculation in garden pansy flowers (Viola wittrockiana) submitted to different levels of irrigation, produced in greenhouse.

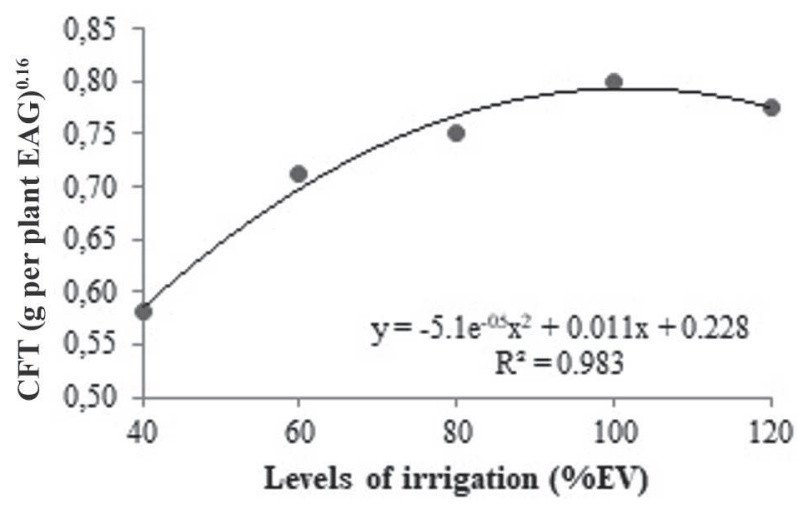

Figure 3: Amount of total phenolic compounds (CFT) (Box Cox transformation, $\lambda=0.16$ ) in garden pansy plants grown in greenhouses under different levels of irrigation.

Table 2: Total anthocyanins content (mg $100 \mathrm{~g}^{-1}$ cyn-3-glu fresh sample) in garden pansy flowers (Viola wittrockiana) submitted to different levels of irrigation and mycorrhizal inoculation (NM: without mycorrhiza; M: with mycorrhiza)

\begin{tabular}{lccccc}
\hline $\begin{array}{l}\text { Mycorrhizal } \\
\text { inoculation }\end{array}$ & \multicolumn{5}{c}{ Levels of irrigation (\%EV) } \\
\cline { 2 - 6 } & $\mathbf{1 2 0 \%}$ & $\mathbf{1 0 0 \%}$ & $\mathbf{8 0 \%}$ & $\mathbf{6 0 \%}$ & $\mathbf{4 0 \%}$ \\
\hline $\mathrm{NM}$ & $96.14 \mathrm{a}$ & $52.65 \mathrm{a}$ & $58.47 \mathrm{a}$ & $57.09 \mathrm{a}$ & $72.13 \mathrm{a}$ \\
$\mathrm{M}$ & $62.53 \mathrm{~b}$ & $75.03 \mathrm{a}$ & $42.95 \mathrm{a}$ & $61.90 \mathrm{a}$ & $71.72 \mathrm{a}$ \\
\hline
\end{tabular}

Means followed by the same letter in the column do not differ by the F test at the 5\% level of significance. 
of the model $(\lambda=0.16)$, there was a significant effect of the interaction between the mycorrhizal inoculation and irrigation levels factors. The irrigation levels did not show a significant difference with mycorrhizal inoculation on total anthocyanins production, except at the level of $120 \%$ $\mathrm{EV}$, which presented the highest amount of total anthocyanins (8.47 mg per plant cyn-3-glu) in the absence of mycorrhiza (NM) (Table 3).

The evolution of the interaction between the irrigation levels and the absence of mycorrhizal inoculation presented a linear trend, indicating that with each $1 \%$ of the water evaporation, there was an increase of $0.005 \mathrm{mg}$ per plant cyn-3-glu in the amount of total anthocyanins (Figure 4-c). As for the split between the irrigation levels and the presence of mycorrhizal inoculation, the total anthocyanins showed a quadratic tendency with a maximum amount of $106.74 \%$ of water evaporation (Figure 4-d).

\section{DISCUSSION}

The relatively low value of the colonization rate in this study indicates low symbiotic responsiveness of the host plant to the fungus used, which may vary in relation to host plant species, mycorrhizal fungus species and environmental conditions, presenting different values for
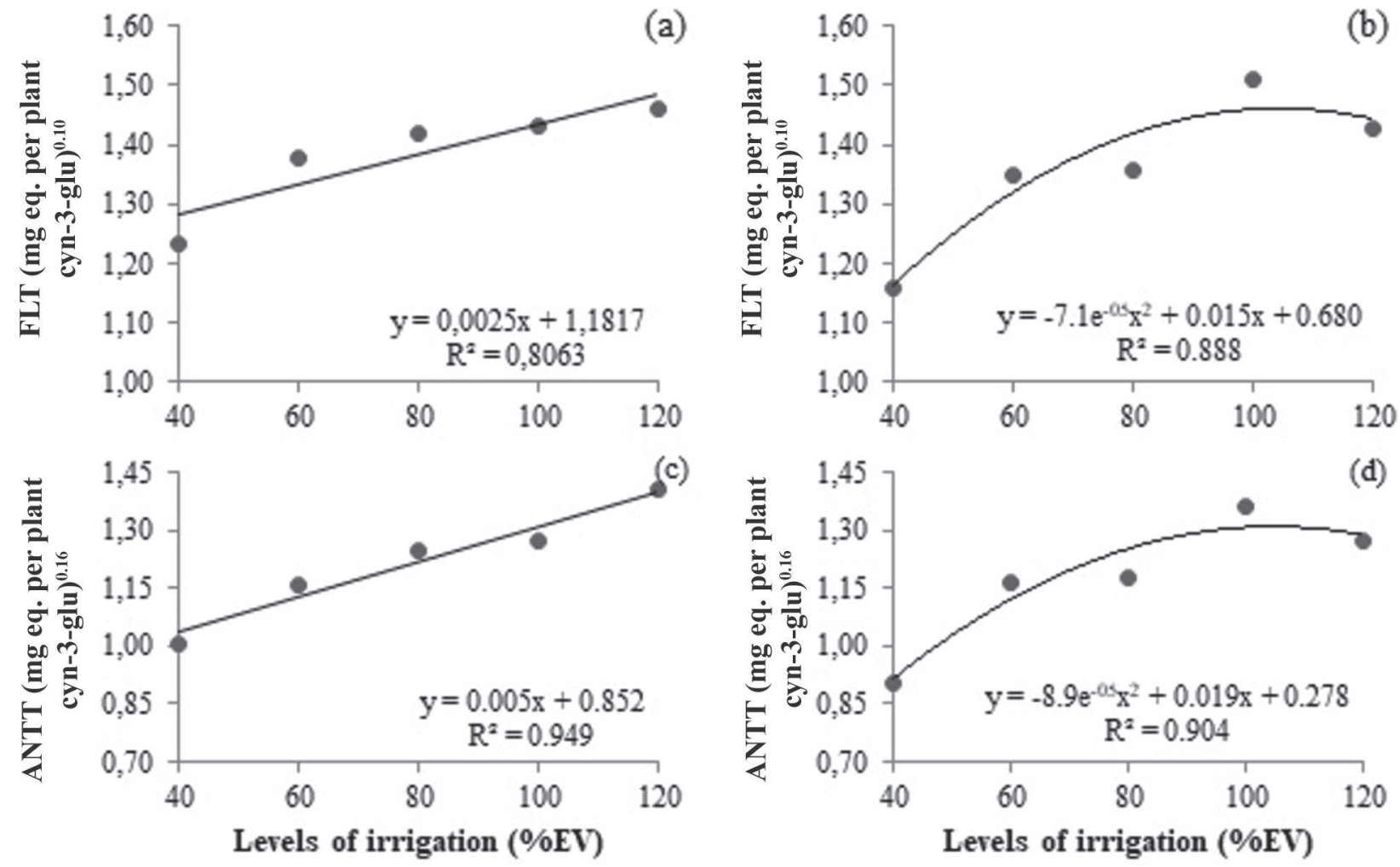

Figure 4: Amount of total flavonoids (FLT) and total anthocyanins (ANTT) (Box Cox transformation, $\lambda=0.10$ and $\lambda=0.16$, respectively) in Garden Pansy plants (Viola wittrockiana) grown in greenhouse under different levels of irrigation with absence (a, c) and presence of mycorrhizal inoculation $(b, d)$.

Table 3: Amount of total flavonoids (FLT) (mg per plant cyn-3-glu) $)^{0.10}$ and total anthocyanins (ANTT) (mg per plant cyn-3-glu) $)^{0.16}$ in garden pansy flowers (Viola wittrockiana) submitted to different levels of irrigation and mycorrhizal inoculation (NM: not mycorrhiza; M: with mycorrhiza)

\begin{tabular}{lcccccc}
\hline \multirow{2}{*}{$\begin{array}{l}\text { Antioxidant } \\
\text { compound }\end{array}$} & $\begin{array}{c}\text { Mycorrhizal } \\
\text { inoculation }\end{array}$ & $\mathbf{1 2 0 \%}$ & $\mathbf{1 0 0 \%}$ & $\mathbf{8 0 \%}$ & $\mathbf{6 0 \%}$ & $\mathbf{4 0 \%}$ \\
\cline { 3 - 7 } FLT & $\mathrm{NM}$ & $1.44 \mathrm{a}$ & $1.42 \mathrm{~b}$ & $1.41 \mathrm{a}$ & $1.36 \mathrm{a}$ & $1.22 \mathrm{a}$ \\
& $\mathrm{M}$ & $1.41 \mathrm{a}$ & $1.50 \mathrm{a}$ & $1.35 \mathrm{a}$ & $1.32 \mathrm{a}$ & $1.14 \mathrm{~b}$ \\
\hline \multirow{2}{*}{ ANTT } & $\mathrm{NM}$ & $1.39 \mathrm{a}$ & $1.25 \mathrm{a}$ & $1.23 \mathrm{a}$ & $1.14 \mathrm{a}$ & $0.98 \mathrm{a}$ \\
& $\mathrm{M}$ & $1.26 \mathrm{~b}$ & $1.35 \mathrm{a}$ & $1.15 \mathrm{a}$ & $1.13 \mathrm{a}$ & $0.88 \mathrm{a}$ \\
\hline
\end{tabular}

Means followed by the same letter in the column do not differ by the F test at the 5\% level of significance. FLT and ANTT Cox Box transformation $(\lambda=0.1 ; 0.16$, respectively)

Rev. Ceres, Viçosa, v. 66, n.6, p. 407-415, nov/dec, 2019 
each situation used (Moreira \& Siqueira, 2006; Smith \& Read, 2008).

The average content of total phenolic compounds $(2.75$ g EAG $100 \mathrm{~g}^{-1}$ fresh sample), found in this study, differs from those found by Grzeszczuk et al. (2016) $\left(0.97{\mathrm{~g} 100 \mathrm{~g}^{-1}}^{-1}\right.$ EAG fresh sample) in $V$. tricolor, by Rop et al. (2012) (0.51 $\mathrm{g} 100 \mathrm{~g}^{-1}$ EAG fresh sample) in $V$. $\times$ wittrockiana and by Vieira (2013) (3.71 g EAG $100 \mathrm{~g}^{-1}$ fresh sample) in V. tricolor, all analyzed by spectrophotometry. In studies of Skowyra et al. (2014), the values of total phenolic compounds found in $V . \times$ wittrockiana were 465.76; 464.17 and $287.51 \mathrm{mg} \mathrm{g}^{-1}$ EAG of dried sample in violet, red and yellow flowers, respectively.

Phenolic compounds are a group of phytochemicals which comprise two other major groups of bioactive compounds: flavonoids, which include anthocyanins, and non-flavonoids, which include phenolic acids (Boroski et al., 2015). To detect significant changes in the profile of phenolic compounds, in relation to the factors studied, further analysis would be necessary.

Zubek et al. (2015) observed that mycorrhizal inoculation promoted increments in only one of the flavonoids evaluated in plants of $V$. tricolor. According to Zeng et al. (2013), increases in secondary compounds due to the use of mycorrhiza are still not very clear in general, and the increase in their production is due to defense reactions of the plant against the mycorrhizal fungus itself (Sbrana et al., 2014). Considering that the mycorrhizal fungus (C. etunicatum) used in this work presented low symbiotic responsiveness, it was inferred that it did not provoke warning signals to the plant, so that it activated its defense system, and thus increase its production of compounds in this case, the group of phenolic compounds, which include the flavonoids.

Although the irrigation factor promoted a significant difference in total flavonoid content, no clear performance was observed, corroborating with what is described by Gershenzon (1984) on the effect of mineral supply and water deficit on the secondary metabolism of plants. In Bortolo et al. (2009) the different irrigation depths applied in the cultivation of Calendula officinalis L. did not alter the total flavonoid contents in the flowers. Already Aleman \& Marques (2016), reported positive increases for the total flavonoid content when water depths were applied were applied, replacing $150 \%$ of evapotranspiration, associated with organic fertilization, in the production of chamomile flower buds. The performance of the flavonoid production in the garden pansy flowers, in front of the irrigation levels used, is in agreement with the result found by Aleman \& Marques (2016) and demonstrates that, at extreme levels of water availability, there is an increase in flavonoid production, possibly aiming to protect the plant against abiotic damage. And, at an intermediate level of water availability, the production of flavonoids remains low, because at that level, there is no warning signaling.

Values different from those found in this study, in the total anthocyanins content, were reported by Benvenuti et al. (2016), which found values of $13.6 ; 12.4 ; 3.31$ and

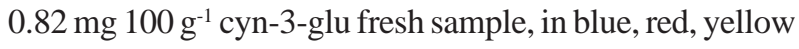
and white $V . \times$ wittrockiana flowers, respectively, and also by Vukics et al. (2008), who found values of 1.52;

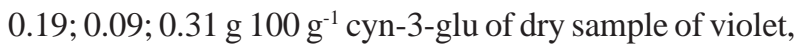
white-violet, white and yellow flowers $(V$. $\times$ wittrockiana $)$, respectively. The different levels of anthocyanins are possibly related to the cultivar of the plant species, edaphoclimatic conditions, harvest season, among other conditions that are capable of promoting changes in the production of secondary compounds in the plants used in the mentioned studies.

Contrasting results of mycorrhizal inoculation on the amounts of total flavonoids and anthocyanins indicate that mycorrhizae accessed a group of flavonoids that did not comprise the anthocyanins. Possibly, the group of isoflavonoids, since these are produced by the host plant to stimulate mycorrhization (Koide et al., 1999).

The amounts of total phenolic compounds produced in the flowers per plant were higher as the water availability for the plants increased. Greater water availability allows greater vegetative growth and greater flower production, consequently, more bioactive compounds per plant are also produced.

The amount of flavonoids and total anthocyanins produced in the flowers showed a tendency to have higher yield per plant in higher percentages of water replacement when not submitted to mycorrhizal inoculation. This fact corroborates with the indication that there was a low symbiotic efficiency between the garden pansy plants and the mycorrhizal fungus $C$. etunicatum. However, it is possible to indicate in this case that the presence of mycorrhiza could have mitigated the effects of water stress, either by the lack or excess of water, reducing the production of secondary compounds that would be used to protect against this water stress (Moreira \& Siqueira, 2006).

In general, the results observed for the production of bioactive compounds, both in relation to their concentrations and in relation to their amounts, demonstrated that the best responses were obtained when $100 \%$ of the water evaporation was used and without use of mycorrhizal inoculation. Among the antioxidant compounds considered in this study, anthocyanins are more important, due to the purple coloration present in the flowers of the Majestic Giants II Rosalyn cultivar, evaluated here, and it was expected that their contents were clearly defined in relation to the other bioactive compounds studied, the which was confirmed with the results found. 
The differences found in relation to the work of several authors mentioned in the contents of the bioactive compounds confirm the variations that such compounds can undergo according to crop, soil, climate, temperature, species and species management (Fernandes et al., 2016).

\section{CONCLUSIONS}

Irrigation and mycorrhizal inoculation have independent effects on the production of total phenolic compounds of Garden pansy, cultivar Majestic Giants II Rosalyn. The best results were observed when $107.8 \%$ of the evaporated water was replaced.

Irrigation and mycorrhizal inoculation effects interact in the production of total flavonoids and anthocyanins of Garden pansy, cultivar Majestic Giants II Rosalyn. The best results for total flavonoids were observed when, in the presence of mycorrhizae, $100 \%$ of the evaporated water was replaced. For total anthocyanins, better results were observed when, in the absence of mycorrhizae, $120 \%$ of the evaporated water was replaced.

Edible flowers of garden pansy have better production of bioactive compounds when irrigated with $100 \%$ of the volume of evaporation of water, and without inoculation with the mycorrhizal fungi Claroideoglomus etunicatum.

This study suggests that new research should be done to find more efficient mycorrhizal fungi in symbiosis with pansy plants, applying more precise methodologies to determine the bioactive compounds present in garden pansy flowers.

\section{CONFLICTS OF INTEREST}

The authors declare no financial or other competing conflicts of interest.

\section{REFERENCES}

Aleman CC \& Marques PAA (2016) Irrigation and organic fertilization on the production of essential oil and flavonoid in chamomile. Revista Brasileira de Engenharia Agrícola e Ambiental, 20:1045-1050.

Antônio M (2013) Paisagismo Produtivo. Revista Brasileira de Horticultura Ornamental, 19:47-54.

Azcón-Aguilar C \& Barea JM (1997) Applying mycorrhiza biotechnology to horticulture: significance and potentials. Scientia Horticulturae, 68:01-24.

Benvenuti S, Bortolotti E \& Maggini R (2016) Antioxidant power, anthocyanin content and organoleptic performance of edible flowers. Scientia Horticulturae, 199:170-177.

Boroski M, Visentainer JV, Cottica SM \& Morais DR (2015) Antioxidantes: Princípios e métodos analíticos. $1^{\mathrm{a}}$ ed. Curitiba, Appris.139p.

Bortolo DPG, Marques PAA \& Pacheco AC (2009) Teor e rendimento de flavonoides em calêndula (Calendula officinalis L.) cultivada com diferentes láminas de irrigação. Revista Brasileira de Plantas Medicinais, 11:435-441.
Box GEP \& Cox DR (1964) An analysis of transformations. Journal of the Royal Statistical Society, 26:211-252.

Chitarra MIF \& Chitarra AB (2005) Pós-colheita de frutas e hortaliças: fisiologia e manuseio, $2^{\mathrm{a}}$ ed. Lavras, UFLA. 738p.

Costa LC, Ribeiro WS \& Barbosa JA (2014) Compostos bioativos e alegações de potencial antioxidante de maracujá, cravo amarelo, rosa e capuchinha. Revista Brasileira de Produtos Agroindustriais, 16:279-289.

Fernandes FS, Souza-Leal T \& Moraes CP (2015) Germinação de sementes de amor-perfeito submetidas à diferentes períodos de exposição e concentrações de $\mathrm{GA}_{3}$. Revista em Agronegócio e Meio Ambiente, 8:601-614.

Fernandes L, Casal S, Pereira JA, Saraiva JA \& Ramalhosa E (2016) Uma perspetiva nutricional sobre flores comestíveis. Acta Portuguesa de Nutrição, 6:32-37.

Gershenzon J (1984) Changes in the levels of plant secundary metabolites under water and nutrient stress. In: Timmermann BN, Steelink C \& Loewus FA (Eds.) Phytochemical Adaptations to Stress. New York, Plenum Press. p.273-320.

Ghini R (2004) Coletor solar para desinfestação de substratos para produção de mudas sadias. Jaguariúna, Embrapa Meio Ambiente. 5p. (Circular Técnica 4).

Giovanetti M \& Mosse B (1980) An evaluation of techniques for measuring vesicular arbuscular mycorrhizal infection in roots. New Phytologist, 84:489-500.

Grzeszczuk M, Stefaniak A \& Pachlowska A (2016) Biological value of various edible flower species. Scientiarum Polonorum, 15:109-119.

Kinupp VF \& Lorenzi H (2014) Plantas alimentícias não convencionais (PANC) no Brasil. Guia de identificação, aspectos nutricionais e receitas ilustradas. São Paulo. Instituto Plantarum de Estudos de Flora. 768p.

Kiriachek SG, Azevedo LCB, Peres LEP \& Lambais MR (2009) Regulação do desenvolvimento de micorrizas arbusculares. Revista Brasileira de Ciência do Solo, 33:01-16.

Koide RT, Landherr LL, Ylva LB, Detweiler JM \& Holcomb E (1999) Strategies for mycorrhizal inoculation of six annual bedding plant species. HortScience, 34:1217-1220.

Lara-Cortés E, Martín-Belloso O, Osorio-Díaz P, Barrera-Necha LL, Sánchez-López JA \& Bautista-Baños S (2014) Actividad antioxidante, composición nutrimental y funcional de flores comestibles de dalia. Revista Chapingo Serie Horticultura, 20:101-116.

Lees DH \& Francis FJ (1971) Quantitative methods for anthocyanis. 6. Flovonols and anthocyanins in cranberries. Journal of Food Science, 36:1056-1060.

Moreira FMS \& Siqueira JO (2006) Microbiologia e Bioquímica do Solo. $2^{\text {a }}$ ed. Lavras, UFLA. 729p.

Mousavi SH, Naghizade B, Pourgonabadi S \& Ghorbani A (2016) Protective effect of Viola Tricolor and Viola odorata extracts on serum/glucose deprivation-induced neurotoxicity: role of reactive oxygen species. Journal of Phytomedicine, 6:434441 .

Neves LC, Alencar SM \& Carpes ST (2009) Determinação da atividade antioxidante e do teor de compostos fenólicos e flavonoides totais em amostras de pólen apícola de Apis mellifera. Brazilian Journal of Food Technology, 7:107-110.

Phillips JM \& Hayman DS (1970) Improved procedures for clearing roots and staining parasitic and vesicular-arbuscular mycorrhizal fungi for rapid assessment of infection. Transactions of the British Mycological Society, 55:158-161. 
R Core Team (2017) R: A language and environment for statistical computing. R Foundation for Statistical Computing. Disponível em: <https://www.R-project.org/>. Acessado em: 01 de março de 2017

Reis C, Queiroz F \& Fróes M (2004) Jardins Comestíveis. Ubatuba, IPEMA. $18 \mathrm{p}$

Rop O, Mlcek J, Jurikova T, Neugebauerova J \& Vabkova J (2012) Edible Flowers-A new promising source of mineral elements in human nutrition. Molecules, 17:6672-6683.

Sbrana C, Avio L \& Giovannetti M (2014) Beneficial mycorrhizal symbionts affecting the production of health-promoting phytochemicals. Electrophoresis, 35:1535-1546.

Singleton VL, Orthofer R \& Lamuela-Raventos RM (1999) Analysis of total phenols and other oxidation substrates and antioxidants by means of Folin-Ciocalteau reagent. Methods of Enzymology, 299:152-178.

Skowyra M, Calvo MI, Gallego MG, Azman NAM \& Almajano MP (2014) Characterization of phytochemicals in petals of different colours from Viola $\times$ wittrockiana Gams. and their correlation with antioxidant activity. Journal of Agricultural Science, 6:93-105.
Smith SE \& Read D (2008) Mycorrhizal Symbiosis. 3 ${ }^{a}$ ed. Amsterdam, Elsivier. 787p.

Vieira PM (2013) Avaliação da composição química, dos compostos bioativos e da atividade antioxidante em seis espécies de flores comestíveis. Tese de Doutorado. Universidade Estadual Paulista, UNESP. 102p.

Vukics V, Kery A \& Guttman A (2008) Analysis of polar antioxidants in Heartsease (Viola tricolor L.) and Garden pansy (Viola $\times$ wittrockiana Gams.). Journal of Chromatographic Science, 46:823-827.

Zeng Y, Guo LP, Chen BD, Hao ZP, Wang JY, Huang LQ, Yang G, Cui XM, Yang L, Wu ZX, Chen ML \& Zhang Y (2013) Arbuscular mycorrhizal symbiosis and active ingredients of medicinal plants: current research status and prospectives. Mycorrhiza, 23:253265

Zubek S, Rola K, Szewczyk A, Majewska ML \& Turnau K (2015) Enhanced concentrations of elements and secondary metabolites in Viola tricolor L. induced by arbuscular mycorrhizal fungi. Plant Soil, 390:129-142. 